\title{
The Geopolitics of Nineteenth-Century Canadian Copyright, as seen by some British Authors
}

\section{Meera Nair*}

\section{Introduction}

It is time that Canadian publishers came over to England and contracted direct with English authors. This personal intercourse between author and publisher would, no doubt, stimulate the latter to greater efforts in order to obtain sales more adequate to the size of the population of Canada than the author obtains under the present arrangement. ${ }^{\mathrm{I}}$

Articulated by The Society of Authors (U.K.) in 1908, these remarks seem innocent enough. To a casual reader, both then and now, they signal a desire for engagement between Canadian publishers and British authors. Yet irony abounds; when Canadian publishers had advocated for such arrangements in the nineteenth century, British authors and their representative publishers had worked diligently to curtail that very engagement, all under the auspices of respecting copyright.

* Meera Nair holds a Ph.D. in communication, with a research interest in contemporary and historical systems of copyright. She is the Copyright Officer for the Northern Alberta Institute of Technology and the author of the blog Fair Duty (https://fairduty.wordpress.com/). It is with pleasure that I thank Sara Bannerman, Eli MacLaren, George Parker, and Myra Tawfik for their encouragement of my interest in Canadian copyright history. The comments provided by two anonymous reviewers greatly enhanced this paper. Throughout, the editors - Janet Friskney, Ruth-Ellen St. Onge, and Myra Tawfik — were generous with their aid and commitment to this special issue of the Papers of the Bibliographical Society of Canada.

I Quoted frequently in this article is the periodical The Author: The Organ of The Society of Authors, edited by Walter Besant and published in London, England, by Alexander P. Watt (I890-9I), by Horace Cox (1894-95), and by Bradbury, Agnew \& Co. (1908). This particular quote is from "General Notes," The Author I8, no. 6 (2 March I908): I72-74 (I72), https://archive.org/details/ theauthori8incouoft. 
Since its legal inception in the U.K. in I7IO, copyright has been promoted as salvation for authors, premised on the belief that what was in the best interests of their publishers would be of benefit to authors as well. There are currents of truth in this perspective, though when adopted blindly the distinctions between literary titans and neophyte authors, between home markets and international territory, and between pricing for an elite readership and pricing for everyday people, are all swept away. That Imperial copyright served as an impediment to the well-being of Canadian authors, printers, and publishers has been well established by several scholars from varying perspectives. $^{2}$

In a previous study, I examined nineteenth-century Canadian copyright difficulties through correspondence between Canada and the Imperial Crown. ${ }^{3}$ Sir John Sparrow David Thompson (I845-94), ${ }^{4}$

2 Gordon Roper, "Mark Twain and his Canadian Publishers: A Second Look," Papers of the Bibliographical Society of Canada 5, no. I (I966): 30-89; James Barnes, "The Canadian Market," in Authors, Publishers, and Politicians: The Quest for an Anglo-American Copyright Agreement 1815-1854 (London: Routledge \& Kegan Paul, 1974), I38-52; James Doyle, The Fin de Siècle Spirit: Walter Blackburn Harte and the American/Canadian Literary Milieu of the I89os (Toronto: ECW Press, 1995), 24; Nick Mount, When Canadian Literature Moved to New York (Toronto: University of Toronto Press, 2005), 26-28; George Parker, "English-Canadian Publishers and the Struggle for Copyright," in History of the Book in Canada, Volume Two: 1840-1918, ed. Yvan Lamonde, Patricia Lockhart Fleming, and Fiona A. Black (Toronto: University of Toronto Press, 2005), I48-58; Catherine Seville, "Colonial Challenges," in Internationalisation of Copyright Law (Cambridge: Cambridge University Press, 2006), 78-I45; Pierre-Emmanuel Moyse, "Canadian Colonial Copyright: The Colony Strikes Back," in An Emerging Intellectual Property Paradigm: A Canadian Perspective, ed. Ysolde Gendreau (Cheltenham: Edward Elgar, 2008), I07-38; Eli MacLaren, Dominion and Agency: Copyright and the Structuring of the Canadian Book Trade I876-I9I8 (Toronto: University of Toronto Press, 20II); Sara Bannerman, The Struggle for Canadian Copyright (Vancouver: UBC Press, 2013), I4-83; Ira Nadel, "Copyright, Empire and the Politics of Print: The Case of Canada," Topia 33 (Spring 20I5): 29-5I.

3 Meera Nair, "The Copyright Act of I889: A Declaration of Independence," Canadian Historical Review 90, no. I (March 2009): I-28.

4 Thompson's tenure in federal politics was brief but he accomplished a great deal. Among many aspects of law reform, working with a bipartisan committee, he took on the demands of preparing Canada's own Criminal Code; J. Castell Hopkins, "The Criminal Code and Copyright Law," in Life and Work of the Rt. Hon. John Thompson (Brantford, ON: Bradley, Garretson \& Co., I895), 38I-9I, https://archive.org/details/cihm_08052. However, Thompson's bipartisan nature was not always appreciated; one of his own party members famously complained: "He won't even consider whether a thing is good for the party 
first in his capacity as Minister of Justice and then as Prime Minister of Canada, strove for years to achieve Imperial recognition of a particular Canadian copyright statute: The Copyright Act of I889. This Act sought to secure payment to a foreign copyright owner in exchange for unauthorized reprinting of the owner's work if, and only if, the owner had not arranged for manufacture and distribution of the work in Canada within one month of publication elsewhere. ${ }^{5}$ Under those circumstances, a Canadian could apply to the government for permission to reprint and distribute in the Dominion, with payment of a compulsory royalty assured. Such a system would have enabled the Canadian publishing industry to grow by meeting the needs of Canadian readers eager for the literature of the Mother Country. ${ }^{6}$ Nevertheless, Imperial consent was withheld.

In this paper, I return to these nineteenth-century events but do so from the perspective of British authors for whose benefit Imperial copyright was deemed to function. A principal source of data is the journal of The Society of Authors (U.K.), aptly titled The Author. ${ }^{7}$ The Society was an organization born of disenchantment, established by authors who felt at the mercy of all publishers and were determined to assert strength through their own numbers. Yet despite an avowed determination to protect their literary property, and to secure better rewards for their labours, British authors were aware of the need for modestly priced works within the colonies. They were equally aware that, with the rise in quality and popularity of American literature among American readers, the window of opportunity for British

until he is quite sure it is good for the country"; quoted in Gordon Donaldson, The Prime Ministers of Canada (Toronto: Doubleday Canada, 1994), 53. For a comprehensive biography, see P.B. Waite, The Man from Halifax: Sir John Thompson, Prime Minister (Toronto: University of Toronto Press, 1985).

5 "Copyright Act of 1889, 2 May 1889," in Correspondence on the Subject of the Law of Copyright in Canada (London: Eyre \& Spottiswoode, I895), no. I, https:// play.google.com/books/reader?id=h-cUAAAAYAAJ\&pg=GBS.PRI.

6 "What the Canadian publisher and printer desire to do is supply the cheap books [wanted by] Canadian readers ... It must therefore, be repeated, that it is desired that the Canadian publisher be permitted to sell in his own market; a market, which under present conditions, is reserved for the benefit of persons outside of Canada" ("Report on Copyright, 7 February I894," Correspondence, no. 43, para. 70-7I). The means by which this state of affairs had come about was a combination of American disinterest in protecting foreign books coupled with its own industry practice that instilled some control over these freely available books; see note 8 .

7 The first issue of The Author was published in May 1894. See Section III, "The Author and its Society." 
authors to profit from the American market was closing. In its initial examination of the Canadian Copyright Act of I889, The Author conveys a willingness to consider compromise - relinquish some autonomy for better fiscal returns - and accept Canada's proposed solution of what today is called compulsory licensing. But The Author also reveals that willingness was abandoned after British publishers intervened and effectively shaped the official position of The Society of Authors. The bitterness felt by the authors with respect to American tendencies to help themselves to foreign books, ${ }^{8}$ together with the Society's ideological underpinnings that copyright is a sacred form of property, enabled British publishers to emphasize that Canada's proposal was an affront to all authors, and that both Empire and the structure of copyright were best governed by tradition.

\section{From Dickens to Trevelyan: Tradition or Innovation?}

Among British authors, discussion of Canadian conduct predated the convening of The Society of Authors. While later in the nineteenth century Canada was seen as an unruly child in danger of being spoilt, Charles Dickens (I8I2-I870) had earlier presented Canada as

8 The U.S. Copyright Act of I79o invited unauthorized uses of foreign works: "That nothing in this act shall be construed to extend to prohibit the importation or vending, reprinting or publishing within the United States, of any map, chart, book or books, written, printed, or published by any person not a citizen of the United States, in foreign parts or places without the jurisdiction of the United States," I Stat. I24 (I790), United States Copyright Office. Despite this freedom, payments were offered to British copyright owners as part of an informal apportioning of control of British works among American publishers, a system known as courtesies of the trade. The core of courtesy prescribed that once a publisher had produced the work of a particular author, it was understood that not only was the work untouchable by any other publishing house, but so too were subsequent works by the same author. Not surprisingly, competition to secure first publication was fierce and led to many private contractual agreements with foreign authors, with provision of upfront payment. Robert Spoo, "The American Public Domain and the Courtesy of the Trade in the Nineteenth Century," in Without Copyright (Oxford: Oxford University Press, 2013), 13-64. However, payment was often contingent on exclusivity across all of North America: "The rights which British authors and publishers have [in Canada] have been greatly abused by the sale of their copyright privileges to American publishers and refusal to sell to Canadian publishers on like terms." ("Lord Stanley of Preston to Lord Knutsford, 7 September i889," Correspondence, no. 3, para. 7). 
dependably British: "But Canada has held, and always will retain, a foremost place in my remembrance. Few Englishman are prepared to find it what it is. Advancing quietly, old differences settling down, and being fast forgotten; public feeling and private enterprise alike in a sound and wholesome state; ... it is full of hope and promise."

Dickens had enjoyed a brief respite in Canada during his first, somewhat fractious American tour in I842. He had publicly scolded Americans for their wanton disregard of international copyright protection, with predictable ire expressed in return: "Dickens seemed to think that there was something noble in the courage with which he put at risk his universal popularity, in order to tell the Americans, face to face, that they were guilty of injustice to himself and to his brother English authors."' However, Dickens's castigation of his audiences was not predicated solely on depicting English authors as victims; he attempted to shore up the merits of recognizing foreign copyright by appealing to American pride in the development of its own writers.

Under the system as it then existed, British works being desirable as well as potentially free to publish, American authors were at a disadvantage for publication. Yet, as Dickens would report, popular response was less than satisfactory: "As to telling them they will have no literature of their own, the universal answer (out of Boston) is, 'We don't want one. Why should we pay for one when we can get it for nothing? Our people don't think of poetry sir. Dollars, banks, and cotton are our books, sir.'"II It was against this backdrop of his

9 Charles Dickens, American Notes for General Circulation, and, Pictures from Italy (London: Chapman \& Hall, I913), I76.

Io E.P. Whipple, "Dickens's American Notes," The Atlantic Monthly 39, no. 234 (April I877): 462-66 (464). https://play.google.com/books/reader? id=IWITeCf v47IC\&printsec=frontcover\&output=reader\&hl=en\&pg=GBS.PA389.

II John Foster, The Life of Charles Dickens (Vol. I) I8I2-I842 (I872; repr., Cambridge: Cambridge University Press, 20II), 32I. Dickens's remarks read as an echo of an earlier American plea; in I828 James Fenimore Cooper wrote to the publishing firm Carey, Lea and Carey: "You will never have a National Literature until you put the Native writers on a level with the English by giving some rights to the latter" quoted in Melissa J. Homestead, American Women Authors and Literary Property, I822-1869 (Cambridge: Cambridge University Press, 2005), 77. But appeals to nationalism were countered with an equally convincing argument: that reprinting underpinned republican dreams; Meredith McGill, "International Copyright and the Political Economy of Prints," in American Literature and the Culture of Reprinting, I834-I853 (Philadelphia: University of Pennsylvania Press, 2003), 76-108. While the words of English literature might remain unchanged, by reprinting works to be affordable, by allowing American editors to collate 
American travels that Dickens saw Canada, and found comfort in its Britishness. ${ }^{\mathrm{I}}$

Eighteen forty-two was also the year of the enactment of an Imperial copyright statute which prohibited unauthorized circulation of British works within Imperial colonies. ${ }^{13}$ Thereafter, colonial readers were expected to partake solely of the expensive volumes produced in London and sent via oceanic voyage (with all the costs and delays involved). ${ }^{\mathrm{I}}$ Colonial readers in British North America were hard hit by this measure, relying as they did on inexpensive American reprints. After appeals to the British Crown for a solution more appropriate to Canada's geography — that of being neighbour to the United States - Colonial Secretary Earl Grey responded in I846 with: "Her Majesty's Government propose to leave to the local Legislatures the duty and responsibility of passing such enactment as they may deem proper for securing both the rights of the authors and the interests of the public."Is

Had Dickens lived to visit Canada in the closing years of the nineteenth century, he may have been on the receiving end of criticism there too, as the Dominion sought the copyright autonomy promised decades earlier. Earl Grey's dispatch had proven to be an empty proposition. The lack of success was marked by several factors: I) a lukewarm effort on the part of English publishers to meet the needs of the Canadian market through cheaper colonial editions; ${ }^{\mathrm{I}}$

material according to their own whims or tastes, republication meant reading was no longer an experience controlled by English publishers. Americans were also keenly aware that their own publishing industry had grown as a result of the collapse of once thriving Irish publishers who fell as a consequence of union with England. "In equating international copyright with a threat to American industry, and locating national identity in the process of production, [publishers and reprinters] made the powerful claim that manufacturing, and not literature, is America's true cultural product" (ibid., 95). See also Adrian Johns, Piracy: The Intellectual Property Wars from Gutenberg to Gates (Chicago: University of Chicago Press, 2009), I45-78. Whatever the rationale, B. Zorina Khan draws a correlation between policies regarding intellectual property during America's antebellum years and the country's ascension from a predominantly agrarian economy to world leader in less than one century; The Democratization of Invention (Cambridge: Cambridge University Press, 2005).

I2 Goldie Morgentaler, "Dickens in Montreal," Dickens Quarterly 19, no. 3 (September 2002): 15I-59.

13 An Act to Amend the Law of Copyright, 5 and 6 Vict. c. 45.

I4 Barnes, Authors, Publishers and Politicians, I40.

is Earl Grey, 5 November 1846, Colonial Copyright (London: HMSO, I872), I3-I4.

I6 From I843-I849, U.K. publisher John Murray attempted distribution of colonial editions of some of his publications, but colonial readers were unimpressed. 
2) British enabling of American printers and publishers to continue their hold on the Canadian market; ${ }^{17}$ and 3 ) further Imperial opinion that Canada lacked the legislative authority to design a copyright law with effect upon anyone other than Canadian readers and writers. ${ }^{18}$ After much negotiation with Britain, Canada had implemented the Copyright Act of I875, ${ }^{19}$ which encouraged British copyright owners to engage with Canadian publishers and arrange for local printing of British works. Yet, being dependent on negotiated agreements between individual British copyright owners and individual Canadian printers or publishers, the i875 Act failed to shift the Canadian market of readers to Canadian publishers. ${ }^{20}$

From Canada's perspective, competing with the United States meant operating under the same conditions, albeit with a critical difference: royalties to British copyright owners were to be compulsory. However, the idea of legitimizing unauthorized reprinting was not welcomed by the British establishment, with the exception of one noted author, Sir Charles Trevelyan (I807-86), ${ }^{2 \mathrm{I}}$

Titles tended to be of a serious nature (not the lighter fare so eagerly sought) and pricing did not decrease sufficiently as compared with American reprints. Other publishers tried as well, but all were wary of those books returning home to compete with highly priced English editions. At that time, "it would have been perfectly possible to license Canadian publishers, an alternative which authors were content with, but publishers were not; they preferred to keep control (and the profits), and to print their own large impressions for all markets" (Seville, Internationalisation, 82-83). See also MacLaren, Dominion and Agency, I7.

17 Foreign Reprints Act I847 (U.K.), IO and II Vict. c. 95. The Act sanctioned circulation of foreign works, subject to securing appropriate compensation to the copyright owner. After protracted negotiations, pirated works produced by Americans were allowed into Canada on payment of a duty, while Canadians were denied the right to produce the works locally, even with the offer of the same payment (Nair, "Copyright Act of I889," 8-9).

I8 By the terms of the Colonial Laws Validity Act I865 (U.K.), 28 and 29 Vict. c. 63, colonies could not legislate contrary to Imperial law. Yet, as Thompson would argue, the Crown had accepted Canadian legislation which conflicted with Imperial statutes; R.A. Shields, "Imperial Policy and the Canadian Copyright Act of 1889," Dalhousie Review 60, no. 4 (Winter 1980-8I): 634-58 (642). See also P.B. Waite, The Man from Halifax, 266-68.

19 Copyright Act of 1875,38 Vict. c. 88, and An Act to Give Effect to an Act of the Parliament of the Dominion of Canada Respecting Copyright, 1875, 38-39 Vict. c. 53.

20 For a detailed account of the intent, British influence, implementation, and effect of the 1875 Act, see MacLaren, Dominion and Agency, I5-I2I.

2I Sir Charles Trevelyan was an author in his own right, and executor for the estate (and thus copyrights) of Thomas Babington Macaulay. As Trevelyan had served 
who strongly supported Canada's compulsory licensing proposal at a Royal Commission tasked with studying the state of copyright in the United Kingdom and the Empire. ${ }^{22}$ The Commission, and Trevelyan's remarks therein, have attracted varied interest, ${ }^{23}$ but Trevelyan's focus on authorial well-being remains under-appreciated.

When asked by the Commissioners to explain the origins of his interest in the area of copyright, Trevelyan pointed to his experiences in the Colonial service, the need for wider diffusion of English literature in India, and his subsequent awareness of the provision of an import tax from all colonies for reprints of English works. Noting that the global returns for works he administered were "perfectly ridiculous," he recalled a better offer that had been proposed by the Dominion of Canada: "In I870 I was informed of an offer made by the Government of Canada to pay a real $12^{1} \frac{1}{2}$ per cent in the shape of

in various positions in India, he saw the inner workings of both copyright and colonialism and brought a different perspective to the entwining thereof.

22 Royal Commission on the Laws and Regulations relating to Home, Colonial and Foreign Copyrights; Report, Minutes of Evidence, Appendix (London: Eyre \& Spottiswoode, I878), xxx. In I892, the British Board of Trade would openly acknowledge that the Canadian situation was "the principal grounds for the appointment of the Copyright Commission of 1876 " "Copyright in Canada, 20 May i892," Correspondence, no. 3I, para. 2I).

23 Catherine Seville described Trevelyan's interest in ensuring the diffusion of English literature in India along with his support for the royalty system in general and Canada's proposal in particular (Internationalisation, IIo). Sara Bannerman also refers to Trevelyan's interest in colonial copyright and explicitly draws attention to the benefits that could have been enjoyed by Canadian industry and British copyright owners: "Canadian reprints of British works would supply the market in India" (Struggle for Canadian Copyright, 29). On the subject of the Royal Commission and the Canadian situation, see MacLaren, Dominion and Agency, 24. Paul J. Saint-Amour provides the most comprehensive treatment of the Commission in "Committing Copyright: The Royal Copyright Commission of 1876-78," in The Copywrights: Intellectual Property and the Literary Imagination (Ithaca, NY: Cornell University Press, 2013), 53-89. With respect to the Commission as a whole, Saint-Amour shows that the very structure of copyright was opened to debate: Should copyright retain its form as a proprietary right, or be restructured to function on the principle of royalty? He further emphasizes that while the proceedings were divisive, history has seized instead on the Commission's final, and somewhat bland assessment: "copyright should continue to be treated by law as a proprietary right, and that it is not expedient to substitute for this a right to a royalty, or any other of a similar kind" (ibid., 54). 
an excise duty upon the actual sale of the works in Canada [instead] of the nominal customs duty of $12 \frac{1}{2} 2$ per cent." ${ }^{24}$

Early in his testimony, Trevelyan challenged the dogma of equivalence between authors and publishers: "The difference between the position of authors and that of publishers underlies the whole subject, and it is better to have it out at once. It is for the interest of the author that his works should be sold anywhere and by anybody ... there should be a general permission to reprint [authors'] works in all British possessions, and that they should have a fair proportion of the proceeds secured to them by the administrative machinery of the respective governments." 25

Aware of the depth of feeling surrounding the principle of control embodied through copyright, Trevelyan attempted to shift the argument to the practical matter of money. "Copyright owners now look to their gains from large profits on small sale, whereas, under the plan proposed, they would get small profits on a large sale. ${ }^{26} \mathrm{On}$ balance, the reward would be greater with the larger sale, and even more so if implemented across all colonies. Regarding the merits ${ }^{27}$ of implementing a royalty system in Canada, Trevelyan placed the inadequacy of customs' collection in the context of an extensive southern border and an audacious neighbour. He emphasized that, as the costs of reprinting were cheaper in Canada, through Canadian partnerships the American market could be turned to British advantage: "Canadians now would be able to carry on an effectual competition with the United States ... Reprints of English copyright works in the United States yield no profit to the author, the reprints in this system would yield a profit." 28

Trevelyan further argued that the blossoming market in the colonies ought to be harnessed to the advantage of authors, not

24 Royal Commission: Minutes, I. Trevelyan divulged that the offer from Canada had sparked a heated exchange of letters between himself and publisher Thomas Longman, and he provided those letters to the Commission (Royal Commission: Appendix, 327). See also Nair, "Copyright Act of 1889," I5-16.

25 Royal Commission: Minutes, 2.

26 Ibid., 3.

27 At the time, and in scholarship thereafter, focus centred on Canada's abysmal results in collecting the customs' duty. It is worth remembering that Canada (in both its colonial and Dominion capacities) did not initially choose such a system, opting instead for local production on a royalty basis. The choice of customs' duties on imported books was the wish of the British Crown; see note 17. See also MacLaren, Dominion and Agency, 17. 
publishers: "The really important matter is, not whether the publishers of England or of America are the most employed and get the greatest profits, but according to what system the largest reward can be obtained for authors ... if we confined our attention to the author's questions, and secured him a reasonable percentage upon the sale of his works, and made the governments of the different colonies responsible for levying that percentage ... he would get a great deal more than he can according to the present system. [Colonial populations] read in far greater proportion than our poor English people do ... and they are increasing far more rapidly than our English people." ${ }^{29}$ Such advocacy appears to have made an impression upon the Commissioners, as their recommendation that colonies engage in a licensing-and-royalty system was unequivocal in the final Commission report. ${ }^{30}$

Trevelyan's staunch belief that authors' copyright interests were distinct from those of publishers was a sentiment shared by many authors; it would ultimately foster the creation of The Society of Authors and its own journal: The Author.

\section{The Author and its Society}

Some Literary Gents the other day did meet

All in a private chamber, which looks on Garrick Street;

There did they meet together, and solemnly they swore

That as they had been done enough they would be done no more. ${ }^{31}$

29 With regard to where current colonial populations received their reading material, Trevelyan was clear: "At present the great manufactory for the supply of reprints of English works abroad is the United States, where our authors do not get a sixpence" (ibid., 7).

30 "We recommend that in case the owner of a copyright work should not avail himself of the provisions of the copyright (if any) in a colony, and in case no adequate provision be made by re-publication in the colony or otherwise, within a reasonable time after publication elsewhere, for a supply of the work sufficient for general sale and circulation in the colony, a license may, upon application, be granted to re-publish the work in the colony, subject to a royalty in favour of the copyright owner ... We do not feel that we can be more definite in our recommendation than this, nor do we think that the details of such a law could be settled by the Imperial Legislature. We should prefer to leave the settlement of such details to special legislation in each each colony" (Royal Commission: Report, xxxiii).

3I "The World greets the formation of The Society of Authors, I2 March I884," The Society of Authors, http://www.societyofauthors.org/About-Us/History. 
The contemporary incarnation of The Society of Authors explains its origins with recourse to these couplets published in early I884, but founding member Sir Walter Besant (I836-190I) placed the date of formation of the Society as September $1883 .{ }^{32}$ He served as the inaugural chair and later took on the role of editor and contributor to the Society's journal, The Author. In the first issue, the central message was clearly stated: literary property "is as real a thing as property in every other kind of business [and] should be safeguarded in the same manner." 33 From whom was such property to be safeguarded? A distinct foe loomed large in the minds of authors as demonstrated by the lead story in the first issue, entitled "Something like a Publisher." Explicit in detail, it narrated the exploits of a con man who entices writers to invest repeatedly in the publication of their work, with no books to show for their eventual financial loss. The story concluded with the partner-in-crime himself being defrauded by the publisher's sham. An Editor's note followed: "The story is literally and exactly true. The man, we have just learned, is beginning the game over again. Moral, - Never answer an advertisement of a so-called publisher without first writing to the Society for advice." 35

While care was taken to distinguish between two breeds of publishers (honourable gentlemen and charlatans), in the subsequent article nothing was left to chance, as this series of commandments

32 [Walter Besant,] "Chapter I2: The Society of Authors and Other Societies," Autobiography of Sir Walter Besant (London: Hutchinson \& Co., 1902), 215-37 (216). Alfred, Lord Tennyson was the first president of the Society, with noted literary members forming the executive and providing coverage across poetry, science, history, theology, fiction, dramatic literature, and journalism (ibid., 219). Besant played many parts on the stage of his own life: mathematician, historian, novelist, and social crusader. One dimension of his pursuit of social justice was his encouragement of authors to become better versed in the machinery of business that surrounds publishing. To that end, the Society's general propositions were: "(I) The maintenance, definition and defense of literary property; (2) the consolidation and amendment of the laws of domestic copyright; (3) the promotion of international copyright" (ibid., 217). The first issue of The Author described efforts that began in 1890 to maintain better communication with members (frequent meetings and issuing pamphlets) with consensus forming around the need for a journal; [Walter Besant], "The Author," The Author I, no. I (I5 May I890): I-3 (I), https://play.google.com/ books/reader?id=xMxYAAAAMAAJ\&pg=GBS.PP7. Ibid.

34 [Walter Besant], "Something Like a Publisher," The Author I, no. I (Is May I890): $3-5(3)$.

35 Ibid., 5 . 
made clear: "Thou shalt not cheat the author in buying his work from him; thou shalt not write or speak lies concerning the cost of preparing his work for press; thou shalt not agree with him on terms such as will give to thyself the profits on his labour. The work is his, not thine at all ... If it becomes thine, it must be by an equitable agreement, which shall give thee a fair reward for labour done, and leave to him all the rest." ${ }^{36}$

Much invective in The Author was reserved for American charlatans and their disregard for British copyright. In reference to a pending American bill which could secure some protection for British authors, ${ }^{37}$ diplomacy was not a concern: "It is satisfactory to know that the tariff men, the petty pirates, and the moneyed ignoramuses - the three classes of which the opposition consists - have so far made a very poor show. During the sittings ... Mr. Roger Sherman, formerly a Philadelphia publisher, declared that 'the outcry for the passage of the Bill was simply the clamour of 200 authors against the interests of 50,000,000 people.' There is a truly delicious naiveté about this confession of a preference for stealing literature instead of buying it." 38

That Bill failed to pass; a later comment in The Author offered a possible solution: "There seems to be but one way for an English author to hold at bay the piratical publishers of the United States: it is to enter into collaboration with an American writer." ${ }^{39}$ Collaboration with a Canadian publisher was not entertained.

The insult of American conduct appears frequently throughout the publication, but so too does acknowledgment that not all Americans were of such ilk. ${ }^{40}$ Sympathetic remarks by American writers were

36 [Walter Besant], "First Principles on Literary Property," The Author I, no. I (I5 May I890): 6.

37 Bill H.R. 694I was introduced by George Everett Adams and given first consideration in the House of Representatives in February I890; William Patry, Copyright Law and Practice, Vol. 2 (Washington, DC: Bureau of National Affairs, I994), I246. See also Thorvald Solberg, "Copyright Law Reform," Yale Law Journal 35, no. I (I925): 56-57, http://digitalcommons.law.yale.edu/ylj/vol35/ issi/9.

38 [Walter Besant], "Notes on Copyright," The Author I, no. I (I5 May I89o): 6-8 (7).

39 Ibid., 8 .

40 For instance, "The attitude taken by the American editors and authors alike on the Copyright Question is everything that can be desired, or, indeed expected of a body of gentlemen"; [Walter Besant], "News and Notes," The Author I, no. 2 (I6 May I890): 25-58 (28). At the Society’s annual dinner that year, support 
reprinted, including one poetic gem by J.D. Gilden, who used rhyme to satirize the piratical practices of the American publishing industry (see figure I).

How it strikes the American author, again, is set forth by Mr. J. 1). Gilden, in "The Critic."

Says Pirate A. to Victim B. :-

"You've got no reason to complain;

Just see how popular you be ;

Your books is read from Tex. to Maine.

"Were not the foreign stuff 'free grat."

I'd buy some native fellow's wares;

Just paste that 'memo.' in your hat,

And don't go puttin' on such airs."

"Aye, true enough my books are read,-

No doubt your imprint makes them sell;

But if on air I must be fted, Why won't that fare serve you as well?

"Henceforth we both will write for fane,I write, you publish, free of charge;

Whatever type proclaims my name, Yours shall be printed just as large.

"Should profits by some chance accrue, Deed them fortinwith to charity :

I'm rich, of course; and as for you,

What's wealth to popularity ?"

Figure I. The Critic, by J.D. Gilden. ${ }^{41}$

Gilden's blunt characterization of wholesale theft obscured the reality that some British authors received payment from American

was personally delivered by George Haven Putnam; see "The Annual Dinner," The Author I, no. 4 (I5 August I890): 90-99 (98). Putnam was the son of George Palmer Putnam, an American publisher who was among the first to set up shop in London and engage with British authors through the system of courtesy payments. Despite opposition from the formidable American manufacturing sector, he pressed for international copyright and throughout was "committed to getting American writers into print, regardless of the cheap availability of foreign literature"; Michael Everton, The Chorus of Complaint: Authors and the Business Ethics of American Publishing (Oxford: Oxford University Press, 20II), II4. Putnam Jr. showed the same spirit as his father.

4I J.D. Gilden, "The Critic," The Author I, no. 2 (I6 June I890): 29. 
publishers. ${ }^{42}$ However, the narrative of theft remained politically sound, given that British copyright owners did not set the amounts received. To a British author, those courtesy payments were illustrations of injustice. An article by Wilkie Collins (I824-89), posthumously published under authority from his estate, took the intent of the Eighth Commandment as its title and returned readers to Dickens's battle with the Americans: "Even Dickens's enormous popularity in England is beaten by his popularity in the United States ... (with international copyright) his work would be worth more in America than in England. What did he get in America for the 'advance sheets?' ... Less than a seventh part of what his English publisher had promised him before a line of his novel had been written - one thousand pounds!" 43

Collins's wrath illustrates a pervasive view of copyrighted works, namely that an unauthorized use represented a lost sale. Often left unexplored is the question of what conditions would ensure that a sale precedes the use. In this instance though, The Society of Authors chose to explore that question. Aware of the reason behind the lack of returns from American readers, the Society sent enquiries to various colonies to determine "how much the author is at present injured by these reprints, which are mostly American, and how far anything could be done to prevent the injury." 44

Some responses conveyed good news. Smaller colonies at an appreciable distance from the source of the "mostly American" reprints, had greater success in policing a customs border. "In Australia and New Zealand, where the Custom House officials levy the duty carefully, pirated editions are by no means rife." 45 Singapore also sent back confirmation that pirated copies were unwelcome on the island, with booksellers agreeing not to keep such copies in stock. ${ }^{46}$

42 The Royal Commissioners had not omitted details of those payments in their final report: "Secured from competition ... it is worthwhile for [American publishers] to rival each other abroad in their offers for early sheets of important works. We are assured that there are cases in which authors reap substantial results ... and instances are even known in which an English author's returns from the United States exceed the profits of his British sale" (Royal Commission: Report, xxxvii).

43 Wilkie Collins, "Thou Shalt Not Steal," The Author I, no. 2 (I6 June I890): 3I-35 (35).

44 [Walter Besant], "English Authors and the Colonial Book Market," The Author I, no. 5 (I5 September I890): III-I4 (III).

45 Ibid., II2.

46 Ibid., II3. 
India posed more of a problem with officials applying Imperial law unevenly; not only were American reprints in circulation, indication was that "copyright books are being printed in secrecy in India." 47 The African colonies posed the greatest problem; works circulated freely, legitimized by way of a twenty percent customs duty which did not affect their affordability. "Pirated American books [sell] at Is. $6 d$... whereas we had only the honest English edition to sell at $6 s . "{ }^{\prime \prime} 8$

The principal response to The Author's query for a solution to the reprint problem is telling: "With great unanimity, the Colonial booksellers pointed out that the most certain remedy imaginable would be to issue cheap authorised editions for the Colonial market ... It is too much to expect that people will give the large sums asked for the English edition, when they can buy the American copies for 25 cents." ${ }^{49}$ Generally speaking, The Author expressed dissatisfaction with the policy of a customs duty; the functioning thereof relied on lists of titles sent from England to the colonies where the delay in reception provided a significant window of opportunity for dissemination of unauthorized reprints. Even when duties were paid, an importer could still undersell the English edition and the demand for reprints continued. ${ }^{50}$ That The Author was describing the Canadian situation to the letter seems to have been lost on the Society.

The desire for better returns from the colonies was perhaps buttressed by the awareness that British dominance, in terms of readership in the American market, was fading. Despite American cheerful disinterest in developing a national literature, as was conveyed to Dickens in 1842, American literature had taken recognizable form by the I89os. Both admiration and fear are evident in The Author:

Enough has been said to show what we are too ready to forget, or to ignore, that there exists across the Atlantic a literature which is comparable with our own in every respect ... the output of original literature of all kinds has become almost as great there as in this country [despite] competition with cheap reprints of British books ... With the enormous development of their own literature it will become increasingly rare for the Americans to want the new books of our production. When, if ever, an International Copyright Bill is passed, those fortunate authors, American or British, who are

Ibid., II2.

Ibid., II3.

Ibid.

so Ibid. 
in demand on both sides, will be few indeed. It will be mortifying when we have got all we have clamoured for to be told that our wares are not wanted. But this seems quite likely to happen. ${ }^{. \mathrm{I}}$

Some pessimism may have been warranted, but again the blindness to opportunity confounds the reader. All was not lost. Acceding to Canada's known request for recognition of the Copyright Act of I889 could have provided British authors with a royalty and a competitive edge in the American market. However, reaping such a benefit required innovative thought not only to the practice of copyright, but to the practice of Imperialism as well.

\section{The Author Responds to Canadian and American Legislation: 1889-1895}

In The Author's assessment of colonial markets, no mention of Canada occurred. As the Empire's first self-governing Dominion, exclusion seems logical. Yet Canada was very much a colony. ${ }^{52}$ Its subservient stature was in full view when The Author began coverage of the Copyright Act of I889: "Canada, it is well known, occupies a peculiar position with regard to copyright legislation. On the one hand, as one of our colonies, literary property receives there the same attention and protection as in any other Imperial Colony. On the other hand, such

5I [Walter Besant], "Recent American Literature," The Author I, no. Io (I6 February I89I): 257-59 (258).

52 In a paper first published in 1942, poet-cum-constitutional-scholar Frank R. Scott offered a closer look at Canada's ambitions for Confederation, and the challenges of realizing them afterwards. The founding fathers had hoped that Confederation would "change the self-governing colonies into a united nation with a stature like that of a partner or ally of Britain ... Allies can be equals but colonies, provinces and dominions are mere British possessions." The words ally and alliance appear in the expressions of Canadian officials as they sought union and independence. British legislators had peppered the first draft of the British North America Act with the word colony, which was then duly struck out by the Canadians. Sir John A. Macdonald, together with the entire Canadian delegation for the London conference, wished for the new entity to be named "The Kingdom of Canada." While the name Canada held, the British Crown afforded the union the "rank" of Dominion. The meaning of this term was unclear as interpretation could mean both "ruled over" and "territory ruled." It seems almost too much of a coincidence that in 1889 a different British Act passed into law, an Interpretation Act that "took care to include the Dominions within the term 'colony."' Frank R. Scott, Essays on the Constitution: Aspects of Canadian Law and Politics (Toronto: University of Toronto Press, I977), 8-I2. 
legislation is very little use to author or publisher. A long and easily crossed frontier between Canada and America renders payment for and publication of copyrighted work a thankless task in Canada; the unshackled American can do the job so much cheaper." 53

W. Oliver Hodges, Honorary Secretary of the Society's Copyright Committee, ${ }^{54}$ prepared an accurate representation of the legislation and the situation which gave rise to it. Among the many details of the Act given were: I) Canada would provide a one-month opportunity for a British copyright holder to arrange for its own publication in Canada; 2) royalties would be set at ten percent with security for such payment to be approved by the Minister; and 3) unauthorized reproductions would be prohibited for import, except that a British edition may circulate if the copyright owner so wished. ${ }^{55}$ Hodges' assessment of the request submitted by Canada was strongly worded: “Sir J. Thompson's report really consists of a powerful argument as to why either the Canadian Copyright Act should receive the Royal Assent; or, if the Crown cannot properly give assent [due to conflict with the Imperial Act], the Government should promote legislation in the Parliament of Great Britain to remove any doubt which may exist as to the power of the Parliament of Canada to deal with the question fully and effectually." 56

With attention to past correspondence between Canada and the Colonial Office, Hodges summarized Canadian difficulties and reminded readers that Canada had been assured by the Imperial Government of support for domestic legislation that addressed the combined challenge of securing returns to British authors and providing reading material to its residents.

Hodges also indicated that The Society of Authors had asked that some response be expressed to the Colonial Office, particularly the desire that the collection of royalties must be suitably robust, together with the following concern: "It appears to the Committee doubtful whether the Canadian Copyright Act ... does not purport to abolish copyright altogether, unless the person entitled thereto reprints or

53 W. Oliver Hodges, "Canadian Copyright," The Author I, no. 7 (Is November I890): $175-77$ (I75).

54 The Committee was composed of "Sir Frederick Pollock, Mr. Lely, Mr. Fraser Rae, Mr. Ross, and Mr. Oliver Hodges as honorary secretary," and assisted by "Mr. Underdown, our honorary counsel, and Mr. Rolt, of the Inner Temple" (Besant, Autobiography, 224).

55 Hodges, "Canadian Copyright," I76.

56 Ibid. 
republishes within one month after printing or publishing elsewhere. At best, the language of the Act is ambiguous on this point." 57 Herein was the interpretation by which Canadian efforts had been, and would again be rejected. A measured loss of authorial control (necessary if compulsory licensing is to achieve its ends) was equated with the abolition of the copyright. Nevertheless, in his closing paragraph, Hodges endeavoured to remind The Author's readers of the importance of context: "It must be remembered, though I hope I may be pardoned for pointing out anything so obvious, that these views of the copyright question in Canada have been forced upon us by the enterprise of America. It is hard on the English author to lose his problematical rights in the colony but the blow is tempered by the remembrance that America has taken due care that he should lose his real rights." 58

Thompson would address these concerns in a letter to Governor General Lord Stanley. He agreed that collection of the royalty must be carefully managed and that the necessary regulations would be determined in concert with the Imperial representative. Thompson also noted, "The Society ... does not renew its request for disallowance nor does it now attack the principle of the Act." 59 However, this moment of mutual understanding between The Author and the Dominion of Canada did not hold; instead, arrangements between Britain and America were formalized in I89I with agreement that copyright for British works could be secured in the United States. ${ }^{60}$ Accustomed as the United States was to gaining exclusive rights over the Canadian market through private arrangements with English copyright owners, a condition of the Anglo-American agreement was that American copyrights would be recognized in the Dominion of Canada. ${ }^{61}$

Praise emanated from Britain, accompanied by the satisfaction of having achieved justice at last. Tongue-in-cheek, The Author offered quotations from letters delivered to President Sherman on the day he signed the American bill, letters written by Britain's finest

\footnotetext{
$57 \quad$ Ibid., 177 .

58 Ibid.

59 John Thompson, Letter to Lord Stanley of Preston, Is December I890, "Sessional Papers (No. 8I)," in Sessional Papers of the Dominion of Canada, Vol. I2, 2nd Sess 7th Parl (Ottawa: S. E. Dawson, I892), I-20 (I7), https://play.google.com/ books/reader?id=zSxOAAAAMAAJ\&pg=GBS.RAis-PAi7).

60 International Copyright Act I89I (U.S.), C.565 26 Statutes at Large iro6.

6I Nair, "Copyright Act of I889," 23-24.
} 
dead authors. Charles Dickens's ghost clearly enjoyed his apparent vindication against the charges levelled by his American critics: "Fifty years ago, I beat the air with my fists, fondly thinking that I was fighting an easy battle against ignorance and greed ... You have shared with us our noble inheritance, the literature of the past; but the baser sort among you have stolen the literature of the present ... Henceforth, however, what is yours is ours, and what is ours is yours." ${ }^{62}$

Despite such rejoicing, the reality was that the United States remained in control of what copyright would mean. Protection against unauthorized reprinting was granted only if the books were printed and published in the United States, on type set within the United States, ${ }^{63}$ prior to or concurrently with publication elsewhere. While the closing issues of Volume I of The Author show enthusiasm for the agreement, disillusionment had set in by Volume II. The core suspicions of the Society were invoked by Charles Godfrey Leland who, although born and primarily educated in the United States, saw the disadvantages of the agreement for both foreign and novice writers: "This is most harassing and unjust to foreign authors. It can only be of profit to those who, having a popular reputation, can secure beforehand a publisher in America ... Should an author publish a book in England alone, and should it by chance turn out to be a success, there is nothing to prevent any American from taking it ... [The Bill] is really and solely devised to favour publishers as much, and authors as little, as possible. Public opinion in Europe, and the complaints of American authors have forced the American publishers and public to grant something, and so they give just as little as they possibly can." ${ }^{\text {"64 }}$ Included in the same article is reference to publisher C.J. Longman's assessment of the American Act: "Mr. Longman points out that those writers whose published works are before the world ... but have failed to attract the attention of pirates, will derive no advantage from the Act ... American printers are clever enough to adapt their type and methods of spelling to adapt to our

62 Quoted in [Walter Besant], "Notes and News," The Author I, no. II (I6 March I89I): 282-86 (283).

63 The financial consequences of this condition were significant as setting type was expensive. In contrast, Canada permitted plates to be imported and on a month's delay, making it feasible to invest in only one set of plates.

64 Charles Godfrey Leland, "The American Copyright Act," Part IV, The Author 2, no. I (I June I89I): 5-II (9-IO), https://play.google.com/books/reader?id= xMxYAAAAMAAJ\&pg=GBS.RAI-PP 3 ). 
needs ... plates will be sent over here and in some cases, books sent over in sheets ... [to the detriment of] British printers and subsidiary trades." 65

At the Annual Dinner of the Society, with Robert Lincoln, son of the late President and now an American minister, in attendance, Chairman Lord Monkswell set out to quell the discontent:

I think, it is no small thing that the American people should have agreed to pay for what they have so long enjoyed without payment ... We know a great deal has been said about what is called the printing clause in the American Act; ... the supporters of the Bill had absolutely no option whatever but to put this clause in. The American Act was only passed by the display of the greatest tact and ability on the part of the promoters of it; and if this sop to American printers had not been put in it is absolutely certain that the Act would never pass into law ... I hope it will be generally recognized that the Americans have gone as far to meet our wishes as we could reasonably hope, and I do trust that not a vestige of irritation or annoyance will remain ... to cloud the perfect understanding that ought to subsist between two peoples so closely allied in blood, and so worthy of one another's friendship. ${ }^{66}$

Such friendship would remain out of reach to those "allied in blood" above the forty-ninth parallel. Thompson continued to press the legitimacy of Canada's case for copyright autonomy to no avail. Canada's proposal seemed to bring a degree of unity to authors and publishers in London; as described by The Author, a meeting was convened to form a special committee where "various copyright interests were represented, namely the musical publisher, the photographer, the Copyright Association, and the Society of Authors. Mr. Daldy, the Honorary Secretary of the Copyright Association, was voted into the chair." ${ }^{67}$ According to The Author, Frederic R.

65 [Walter Besant], "The American Copyright Act," Part VI ("Mr. C.J. Longman on the Bill"), The Author 2, no. 1 (1 June 1891): 5-11 (11). This article cites C.J. Longman, "The American Copyright Bill," The Economic Review I, no. 2 (April I89i), 203-8.

66 "The Annual Dinner on I6 July I891," The Author 2, no. 3 (I August 9I): 69-80 $(72-73)$.

67 [Walter Besant], "Literary Property: Canadian Copyright," The Author 5, no. I (I June I894): 5-6 (5), https://play.google.com/books/reader? id=HXBbEVixthMC\&pg=GBS.PP7. Publisher Frederic R. Daldy had a long tenure as an English representative with respect to the Canadian copyright file; he first became involved in Canadian matters in 1869 (MacLaren, Dominion and Agency, 28-29). Despite Daldy's position as a representative of the Copyright 
Daldy described his past correspondence with the Colonial Office in connection to Canada but The Author does not provide details. Daldy likely reassured his listeners that he had vehemently objected to the Copyright Act of I 889 after it was unanimously passed by the Canadian Parliament. ${ }^{68}$

In that same article The Author invited readers to return to the issue of November I890 and review Hodges's assessment of Canada's proposal; however, two months later a markedly different opinion supplanted Hodges's analysis: "[I cannot] usefully follow all the arguments [of Sir John Thompson's memorandum] ... They are based on the fallacy that some Canadian publishers and printers have some inherent right to have the profit of publishing and printing the work of British authors, and that if the latter do not find it necessary or convenient to publish or print in Canada the Canadian Legislature has right to make them do so." ${ }^{69}$ As had too often occurred before, context was removed and the dilution of control again portrayed as wholesale appropriation of rights and profit.

In late 1894, Thompson travelled to London, to be sworn in as a member of the Queen's Privy Council and to discuss, among other matters, the copyright situation. Before Thompson's discussion, members of the special committee had sought leave to speak to the Colonial Secretary, the Marquis of Ripon, and had presented their view that Canada's proposal would destabilize American concessions and spark dissention within the Empire. The Author provided detailed coverage of the discussion, capturing the thrust offered by each speaker. Among the remarks made were:

Walter Besant: "Should a country of five million be allowed to wreak all this mischief and wrong upon a world of $\mathrm{I} 2 \mathrm{O}$ million

Association, which comprised authors and publishers, a letter he wrote in 1872 in which he describes the means to resolve the Canadian difficulties in Britain's favour, betrays his bias: "the word author does not appear" (Seville, Internationalisation, 94-96).

68 At that time Daldy had insisted that the Royal Commission's recommendation of licensing in the colonies was not applicable to Canada ("F. R. Daldy Esq to Colonial Office, 22 February i890," Correspondence, no. 5). Such a conclusion is inconsistent with the Commission Report; the discussion preceding the recommendation of compulsory licensing delves into Canadian experiences. Furthermore, Trevelyan was the first witness to speak to the Commission and it was within the context of Canada that he introduced the conceptual basis of a system based on licensing and royalties.

69 J. Rolt, "Literary Property: Canadian Copyright," The Author 5, no. 3 (I August I894): 63-68 (66). 
in order to enrich two or three publishers by underselling the Americans?"

Mr. F.R. Daldy: "After consulting with the American Authors Association and leading publishers ... to accede to Canada's request would more than jeopardise the [Anglo-American agreement]."

Mr. H.O. Arnold-Forster, M.P.: "What would be the consequence if other parts of the Empire were allowed the privileges sought by Canada?"

The Marquis of Ripon, in reply: "Sir John was now in England ... Of course [the committee] would understand that the desires expressed by one of the great colonies were entitled to the most serious consideration of the Imperial Government [but] that Government was bound not to overlook the interests of persons to whom the world was as much indebted as [these] representative authors and publishers." ${ }^{\circ}$

Indebtedness notwithstanding, in the days prior to his swearingin ceremony, Thompson achieved some recognition within the Colonial Office of the legitimacy of Canada's position: "The claim of the Canadian legislature is a good one, and the burden of proof that it is contrary to public policy rests on those who contest it." ${ }^{\text {II }}$ The ground thus gained was never capitalized on. A few hours after the swearing-in ceremony, on I2 December I894 at Windsor Castle, Thompson collapsed and died.

Thompson's sudden death meant that the question of whether the Dominion of Canada had the legislative authority to proceed with a statute deemed to be in conflict with an Imperial statute was never adequately resolved. Yet such a question would have been irrelevant if Canada had enjoyed the regard of being an ally. As Hodges noted, if the British Government felt that existing Imperial law forbade provision of Royal Assent, the British Crown could well enact legislation to address that need. The Canadian government made some effort to continue to press for the Copyright Act of I889, but opposition only gained in intensity. The Society of Authors pleaded with the British Government to withhold assent and publicly framed the dispute as an assault by Canadian publishers and reprinters on

70 [Walter Besant], "Literary Property: Deputation on Canadian Copyright," The Author 5, no. 7 (I December I894): I7I-73.

${ }^{71}$ Quoted in P.B. Waite, "Sir John Thompson and Copyright, I889-1894: Struggling to Break Free of Imperial Law," Bulletin of Canadian Studies 6, no. 2 (Autumn 1983): 36-49 (49). 
British authors. In a letter to the Times, dated 26 February I895, the Society launched a petition condemning the Canadian $\mathrm{Act}^{72}$ and received support from more than I,500 individuals within two months. ${ }^{73}$

The Society even invoked a touch of celebrity influence in condemning Canada, amplifying the words of literary sensation Hall Caine. Despite The Author's earlier rueful acknowledgement that American authors had risen from a pirate-regime oriented towards widespread reading, that American literature could in fact compete with British literature, ${ }^{74}$ Caine painted a harsh and bleak picture regarding Canada's proposal of compulsory licensing with royalties: "As long as [Canada] is a literary pirate, or at best the dispenser of a copyright which is no copyright at all but only a sham and a mockery, she will never develop a literature of her own ... no Canadian literature will be able to exist side by side with a pirated literature."75

Over the next few months, the Society deputized Caine to represent British views at meetings in the United States and Canada; ${ }^{76}$ he was effective and set in motion a revision of Canadian law in a manner more consistent with British and American wishes. ${ }^{77}$ Notably, "Mr. Daldy expressed himself satisfied with the general principles of the proposed measures. ${ }^{\prime 7}$ Even so, several more rounds of discussion would ensue before Canada's Copyright Act was amended in $1900 .{ }^{79}$

72 W.M. Conway, "Literary Property: Canadian Copyright," The Author 5, no. Io (I March I895): 256-62 (262).

73 G.H. Thring, "Literary Property: Canadian Copyright," The Author 5, no. II (I April I895): 283-86 (285).

74 See note $5 \mathrm{I}$.

75 Hall Caine, "The Canadian Copyright Act," The Contemporary Review 67 (April I895): 477-8I (48I). Caine's work was among a collection of articles, and given added publicity via The Author: "On the proposed Canadian Act, a small collection of opinions from three authors and two publishers appeared in the Contemporary Review in April ... It is shameful that a country like Canada should for a moment entertain a proposal to revert to the old time of international piracy"; [Walter Besant], "Notes and News," The Author 5, no. I2 (I May I895): 316-I9 (317).

76 [Walter Besant], "Literary Property: Canadian Copyright," The Author 6, no. 3 (I August 1895): 55, https://play.google.com/books/reader?id= HXBbEVixthMC\&pg=GBS.RAI-PPI).

77 [Walter Besant], "Literary Property, Canadian Copyright," The Author 6, no. 7 (2 December I895): I5I-52 (I5I).

78 Ibid., I52.

79 An Act to Amend the Copyright Act, I9oo, 63 and 64 Vict. c. 25. Compulsory licensing was no longer sought but local manufacturing remained critical; 


\section{Conclusion}

For many Canadians in the nineteenth century, national existence was set in service to Britain, where loyalty necessitated some loss of independence. Sir John Thompson harboured wider aspirations; Peter Waite captures Thompson's capacity to be both loyal and independent in a single sentence: "The Parliament at Westminster did not make [Thompson] feel inferior but confident." ${ }^{10}$ Thompson was proud of his Canadian birth and saw in his nation a country capable of existing in its own right. Co-operation with, and reciprocation from, Britain was the expected outcome of a responsible government that took justice and the rule of law as a dual lodestar. ${ }^{81}$

But the arena of copyright was to disprove Thompson's expectations; legal acumen and logical appeals to fairness were no match against the established industries of Britain or America. The lengthy border between Canada and the United States that facilitated unauthorized distribution was addressed not by adapting law to meet unavoidable circumstances, nor by seeking opportunity in unalterable geography, but by retreating into the rhetoric of Empire and copyright. Admittedly, rhetoric was useful - it could silence dissent with shame and threat of censure. The mantra of Empire was taken as reason not to bend to the wishes of a colony, suggesting that,

copyright was to be obtained through reproduction in Canada from "movable or other types, or from stereotype plates, ... or by any process for facsimile reproduction" (ibid). Coupled with excluding unauthorized reprints from circulation, it was hoped that Canadian firms would become exclusive distributors for British works. However, foreign firms became adept at using these provisions via their own Canadian subsidiaries (MacLaren, Dominion and Agency, I22-26). When Frank Wise, first president of Macmillan of Canada, requested that capital be kept for publication of promising local works, displeasure came quickly from the head office: "The only kind of publishing which ought to originate in Canada is the production of school books authorized by one of the Provincial governments" (ibid, I24). Wise's successor, Hugh Eayrs, was similarly chastised; George Parker, "The Struggle for Literary Publishing: Three Toronto Publishers Negotiate Separate Contracts for Canadian Authors 1920-1940," Papers of the Bibliographical Society of Canada 55, no. I (2017): 5-50 (3I).

80 Waite, The Man from Halifax, 262.

81 Waite gives extensive coverage of Thompson's efforts to resolve critical fishing disputes between the United States and Canada (thus by implication, Britain). This earned Thompson a British honour - Knight of Commandership of St. Michael and St. George (ibid., 22I). Thompson would later write to Lord Ripon thanking the Colonial Office for the sympathy felt and shown "towards my country as regards her claim for justice and fair treatment” (ibid., 262). 
when a reason exists, logic and fact become irrelevant. Likewise, the presumed sanctity of copyright enabled British publishers to profit from the Canadian market by entering into exclusive North American arrangements with American publishers. One hundred and thirty years later, all that can be said is that Canada's nineteenth-century innovative approach to copyright had the potential to increase revenues for British authors, and was initially supported by British authors, but was not put into practice.

\section{SUMMARY}

Following Confederation, Canada was deemed a Dominion and provided with sufficient powers to conduct its own affairs. But the de facto experience was that when its affairs crossed international borders, Imperial preferences took precedence and Dominion reverted to colony. The arena of copyright was no exception.

American publishers had captured the Canadian reading market through both piracy and private arrangements with British copyright owners. The Canadian government tried to regain its market through an innovative measure which would provide compensation to foreign copyright owners and foster Canadian publishers and authors. That proposal was firmly denied by Britain; it sought instead to hold Canada to the role of customs officer with respect to the duties owed for unauthorized American reprints circulating in the colony. This historic fact is not in doubt; but a study from the perspective of British authors, largely through the journal of the Society of Authors (U.K.), offers insight into these nineteenth-century events. Intriguingly, British authors had shown an intelligent awareness of the difficulties surrounding reading in the colonies and, both implicitly and explicitly, gave some support for Canada's proposal. However, stronger voices from within the British publishing sector ensured that copyright remained bound by tradition.

\section{RÉSUMÉ}

Durant les années et les décennies qui ont suivi l'adoption de la Confédération, le Canada était perçu comme un dominion détenant 
des pouvoirs suffisants afin de gérer ses propres intérêts et dossiers. Mais lorsque ces derniers transcendaient les frontières du pays, les priorités de l'Empire britannique primaient et le Dominion du Canada était alors à nouveau relégué à son statut de colonie. La question du droit d'auteur ne faisait pas exception à cette règle.

En privilégiant la contrefaçon et en établissant des ententes avec des détenteurs de droits britanniques, les éditeurs américains avaient autrefois réussi à exercer une mainmise sur le marché canadien. Jugeant cette situation inique, le gouvernement canadien a tenté de reconquérir son propre marché par le biais d'une mesure novatrice qui prévoyait une compensation financière pour les détenteurs de droits étrangers et qui favorisait les éditeurs ainsi que les auteurs du Canada. Cette proposition a été rejetée en bloc par la Grande-Bretagne, qui cherchait plutôt à cantonner le Canada à son rôle de douanier (tout en affichant le plus grand respect pour cette fonction) et de vigile, ne serait-ce qu'en raison des réimpressions américaines non autorisées qui circulaient alors dans la colonie. Un tel fait historique n'est d'aucune façon remis en question dans cet article, qui jette un nouvel éclairage sur ces événements du dix-neuvième siècle, notamment en privilégiant les points de vue des auteurs britanniques, tels qu'on les retrouve dans la revue de la Society of Authors (UK). Fait étonnant : plusieurs auteurs britanniques s'étaient déjà montrés conscients des difficultés liées à la lecture dans les colonies d'Amérique du Nord et sensibles à cette problématique : c'est pourquoi bon nombre d'entre eux ont implicitement ou explicitement appuyé la proposition du Canada. Cependant, des gens du milieu du livre britannique, jouissant d'une grande autorité, ont fait en sorte que la gestion des droits d'auteur reste intrinsèquement liée à la tradition et ne change pas. 